\title{
Europe and Rights: Taking Dialogue Seriously ${ }^{1}$
}

\author{
Marta Cartabia
}

\section{Introduction - the new millennium: a constitutional era for the European Union?}

Despite the failure of the ambitious project of the European Constitutional Treaty and the difficult path towards the ratification of the Treaty of Lisbon, the new millennium has indeed heralded a new constitutional era for the European Union. Some relevant constitutional changes are taking place in the first decade of the $21^{\text {st }}$ century, and most of them concern fundamental rights. Since the approval of the Charter, fundamental rights have taken a place of honour in the European agenda - as the setting up ${ }^{2}$ of the European Union Agency for Fundamental Rights in Vienna proves. Moreover, the Charter has brought fresh constitutional fuel to the European Court of Justice's engine. It seems that the availability of a written catalogue of fundamental rights encourages the Court of Justice to act as a federal constitutional court. ${ }^{3}$ In fact, a new phase of judicial activism has begun in the European Court of Justice, a phase focussed on the protection of fundamental rights. Whereas the European Union is not having its most auspicious moment as regards its political cohesion, the Europe of judges and rights is flourishing. As had been predicted, ${ }^{4}$ a Grundrechtsgemeinschaft is quickly developing.

1 This article was previously published in European Constitutional Law Review, 5: 5-31, 2009.

2 The European Union Agency for Fundamental Rights was established by Council Regulation (EC) No. 186/2007 of 15 Feb. 2007. On this point see A. von Bogdandy, 'The European Union as Situation, Executive, and Promoter of the International Law of Cultural Diversity - Elements of a Beautiful Friendship', Jean Monnet Working Paper 13/07, in http://www.jeanmonnetprogram.org/papers/07/071301.pdf visited 23 Jan. 2009.

3 Most scholars think that the ECJ acts as a constitutional courts at least in some cases, although they not always support the proposal of transforming the ECJ into a special judge deciding only constitutional issues: O. Due, 'A Constitutional court for the European Communities', and F.G. Jacobs, 'Is the Court of Justice of the European Communities a Constitutional court?', in D. Curtin, D. O'Keeffe (eds.), Constitutional Adjudication in European Community and National Law (Butterworth, Ireland 1992), p. 2 and p. 25; B. Vesterdorf, 'A Constitutional Court for the EU', 4 International Journal of Constitutional Law (2006), p. 607. See however L. Favoreu, 'Les Constitutions nationales face au droit européen', 28 Revue française de droit constitutionnel (1996), p. 699 who affirms that at present the ECJ cannot be considered a constitutional court, because it still lacks of too many important elements, such as a veritable Constitution of the EU, an impartial appointment of judges and many others.

4 A. von Bogdandy, 'The European Union as a Human Right Organization?', 37 Common Market Law Review (2000), p. 1308. Soon after the solemn proclamation of the Charter of Rights by the European Union in Nice on $7^{\text {th }}$ Dec. 2000, Armin von Bogdandy sensed the first symptoms of an evolution destined to change the features of the European integration, from an economic community towards a Grundrechtsgemeinschaft, a community of fundamental rights. As the author had predicted, the Charter of Fundamental Rights actually marked a new era in the European integration, displaying all its seductive power. Later the author changed his thesis as can be read in the paper above mentioned in $n .1$. 
In a certain sense this evolution is déjà-vu: many other stages in the history of the European integration have been marked by the weakness of the political process and by the activism of the judicial branch. After all, it is quite common that political failures leave room for judicial activism. So, it is no wonder that since the political path to a fully-fledged European Constitution was closed, the European Court of Justice is again in the centre of the constitutional arena.

What is more distinctive of the new wave of judicial constitutional activism is an intense activity in fields related to fundamental rights. In this domain the member states display both a common background and different traditions at the same time: social rights, family law, state and religion - just to mention some examples - are fields where the 27 member states have different legal regulations. All this considered, the European Charter of Fundamental Rights put in the hands of the Court brings about many benefits but also some risks, the most obvious one being that of centralisation and homogenisation.

In danger is the pluralistic 5 nature of the European Constitution, the "contrapunctual'6 elements of the constitutional equilibrium, the principle of constitutional tolerance ${ }^{7}$ and the mutual nourishment between the national and the European constitutions. ${ }^{8}$

A fundamental antidote to the risk of judicial standardisation in the field of fundamental rights is a lively judicial dialogue among the constitutional courts in Europe by means of the preliminary ruling. This is at present the most effective tool available in the European Union to allow the national constitutional traditions to be conveyed before the European Court of Justice, especially in cases involving human rights.

That is the reason why this paper intends to insist once again on the wellknown issue of the judicial dialogue 9 in the European Union. The paper recalls and briefly analyses some leading decisions of recent case-law of the European Court of Justice on human rights in order to appreciate the dramatic evolution of the European constitu-

5 On pluralism as the contemporary model of relationship in the EU see N. MacCormick, Questioning Sovreignty: Law, State and Nation in the European Commonwealth (Oxford, Oxford University Press 1999), p. 120 and the rich debate triggered by this essay.

${ }^{6}$ Recalling a famous definition by M. Poiares Maduro, 'Contrapunctual Law: Europe's Constitutional Pluralism in Action', in N. Walker (ed.), Sovereignty in Transition (Oxford, Hart Publishing 2003), p. 501.

7 The reference is to those authors who emphasise the pluralistic nature of the European Constitution, such as J.H.H. Weiler, who is the father of the idea of constitutional tolerance. See: The Constitution of Europe (Cambridge, Cambridge University Press 1999), at p. 238 et seq.

8 I. Pernice, 'Multilevel Constitutionalism in the European Union', 27 European Law Review (2002), p. 511 et seq.

9 Whereas the legal literature on the judicial dialogue is almost boundless, it is worth noting that some scholars criticize the idea of a judicial dialogue in itself, contending that dialogue is a common practice within the political institutions, but is almost impossible among courts and judges. See B. De Witte, 'The Closest Thing to a Constitutional Conversation in Europe: The Semi-permanent Treaty Revision Process', in P. Beaumont, C. Lyons, N. Walker (eds.), Convergence and Divergence in European Public Law (Oxford, Hart Publisbing 2002) 
tional balance in the field of fundamental rights since the approval of the Charter. It is not so relevant to record how many times the Charter of Rights has been explicitly quoted in the European Court's decisions: although for some years the Court was reluctant to quote the Charter, 10 its influence on the case-law of the Court of Justice greatly exceeds the formal references and it can be appreciated by observing the fundamental rights in action, i.e., in the practical application of judicial cases. Keeping in mind the dramatic changes that are occurring in the protection of fundamental rights in the European Union, the persistent refusal of many constitutional courts to enter into direct judicial dialogue with the European Court of Justice lacks justification. The European constitutional balance urges a plural constitutional dialogue: a strong and daring European Court of fundamental rights needs to be surrounded by similar strong and daring interlocutors at national level. A step needs to be taken from both sides to favour an encounter among the actors of the European constitutional drama: the national Constitutional Courts should abandon their reticence to address directly the European Court; the latter, for its part, should do its best to encourage the judicial dialogue, which would in the first place be in its own interest.

\section{Signs of constitutional activism in the case-law of the European Court of Justice on fundamental rights}

Although the Charter approved in 2000 does not represent the first form of protection of fundamental rights in the European Union, but on the contrary is integrated in a process established back in the 1960s and consolidated over time, it is undoubtedly a turning point, considering the quality and quantity of the Court of Justice's interventions on fundamental rights. Some feared that the Charter would chill the creativity of the European Court of Justice, but the result seems to be exactly the opposite. Facts show that the Charter is strengthening rather than di-minishing the interpretative and creative ability of the European Court.

A rich list of decisions regarding human rights corroborates this hypothesis. Below are some of the most distinguished examples.

\section{The Tanja Kreil case}

The starting point of the new dynasty of constitutional cases can be considered the Tanja Kreil decision in 2000,11 a sentence pronounced before the approval of the Charter, but in the midst of the mood of constitutional euphoria that pervaded the European Union in those years. It is not necessary to recapitulate in detail such a famous case, which has been discussed by many, but suffice to remember that all in all it presented

10 The first decision where the European Court of Justice quotes the Charter is decision 27 June 2006, Case C-540/03, Parliament v. Council where the Court refers to the directives regarding the reunion of family, which in turn mentions as a premise the Charter of Rights. After that case the ECJ arguments refer to the Charter without hesitation.

${ }^{11}$ ECJ 11 Jan. 2000, Case C-285/98, Tanja Kreil. 
the Court of Justice with a constitutional conflict between a provision of the German Constitution, Article 12 of the Grundgesetz, which forbade women to carry out roles in the army that implied the use of arms, and a basic principle of Community law, notably the principle of non-discrimination on the basis of sex. Without beating about the bush, the Court of Justice states that the Community principle of non-discrimination 'precludes the application of national provisions, such as those of German law, which impose a general exclusion of women from military posts involving the use of arms and which allow them access only to medical and military music services.' Without insisting explicitly on the constitutional rank of the relevant German norms, the Court of Justice concludes by demanding a constitutional revision on the part of Germany, pointing out an irredeemable conflict between the Community law and the national Constitution. So, while the Court of Justice up until then had prevented the flaring-up of conflict between national Constitutions and Community principles, ${ }^{12}$ in the Kreil case there was no hesitation in obliging the Germans to come into line with the European principles by revising their Constitution. That is precisely the reason why Tanja Kreil can be considered as the forerunner of the new line of decisions of the European Court on human rights.

\section{The Schmidberger and Omega cases}

From another viewpoint, important signs of novelty can be seen in some decisions regarding conflicts between the fundamental economic freedom and human rights.

Critics of the Court of Justice have often expressed suspicion about the authenticity of the Community's guarantee of fundamental rights. It has been repeatedly highlighted that the Court of Justice has exploited the rhetoric of human rights, aiming not so much at the protection of some basic values in themselves, as rather at strengthening economic integration. ${ }^{13}$ In fact, for a long time, the Community protection of fundamental rights was highly conditioned by the general objectives of European economic integration and so first and foremost by the common market. Until very recently, the Court of Justice has shown great deference for the economic freedoms of the common market: each time it has been necessary to set a balance between them and other fundamental rights. Indeed, the Court of Justice has never dealt with either fundamental freedoms nor fundamental rights as absolute values and consequently has always been careful to keep a balance between the reasons for economic freedom and those for fundamental rights. However, in this complex balance, economic freedoms have often had the upper hand.

12 Suffice to recall the well-known decisions of the ECJ concerning the Irish Constitution: ECJ 28 Nov. 1989, Case C-379/87, Groener, on the protection of the Gaelic language and ECJ 4 Oct. 1991, Case C-159/90, Grogan, on the right to life and abortion.

13 J. Coppel - A. O’Neill, 'The European Court of Justice: Taking Rights Seriously?', 29 Common Market Law Review (1992), p. 669. 
And so, that explains why the Schmidberger case of $2003^{14}$ was enthusiastically welcomed by many scholars and commentators. In that decision, the Court of Justice, called upon to resolve a controversy between a basic freedom of the market - in that case the free movement of goods - and some fundamental rights - the freedom of assembly and the freedom of speech - caused by a demonstration by an environmental association that blocked the Brenner motorway for 30 hours, surprisingly gave prevalence to the latter, in a balancing decision in which, for once, civil rights prevailed over economic interests.

Even more astonishing, in many respects, was the Omega decision in 2004.15

Also in this case the Court of Justice had to face a conflict between an economic freedom protected by the Treaty, specifically the free movement of services and to a lesser extent the free movement of goods, and the protection of fundamental rights, which in this specific case regarded human dignity in relation to a commercial service of entertainment offering games that simulate murders using toy laser guns.

The case could have been solved on different grounds, but the Court did want to use the discourse of fundamental rights by affirming that human dignity is not only one of the basic values of the German Constitution, but it is also part of the values of the European system. The Court of Justice did want to stress deliberately the commitment on the part of the European Union towards the respect for human dignity. When one reads the Omega decision, it is difficult not to perceive the subtle influence of the Charter of Fundamental Rights that opens precisely with the claim that the safeguarding of human dignity is an inviolable right. The efforts of the Court of Justice did not go unobserved.

So in Omega, as in Schmidberger, fundamental rights prevailed over economic freedoms and justified the important restrictions placed on them.

\section{K.B., Richards and Tadao Maruko cases}

From another point of view, it can be seen that in more recent years the Court of Justice tends to widen the scope of community fundamental rights, going beyond the limits of the European Union competences that the doctrine of incorporation would permit. This tendency is clearly visible in some cases regarding the rights of transsexuals: K.B. ${ }^{16}$ and Richards. ${ }^{17}$ Both cases originate in Great Britain, where at the time of the events a peculiar legal situation was in force, which on the one hand permitted a change of sex, it even being covered by the national health service; on the other, however, it did not allow the change of sex to be recorded in the registry office, preventing the transsexual from enjoying the status reserved to the person of the sex to which

14 ECJ 12 June 2003, Case C-112/00, Schmidberger. On this issue M. Avbelj, 'European Court of Justice and the Question of Value Choices', http://www.jeanmonnetprogram.org/papers/04/ 040601.pdf visited 25 Jan. 2009.

15 ECJ 14 Oct. 2004, Case C-36/02, Omega.

16 ECJ 7 Jan. 2004, Case C- 117/01, K.B.

17 ECJ 26 April 2006, Case C-423/04, Richards. 
she/he belonged after the operation. In the cases brought to the attention of the Court of Justice, the impossibility of registering the change of sex prevented the plaintiff from entering into marriage and thus from enjoying the survivor's pension, in one case, and from being able to retire at 60 - the age for women's retirement - in the second case. In both cases British law was judged incompatible with the principles of nondiscrimination on the basis of sex and the United Kingdom, on several occasions censured by the Court of Luxemburg as well as by the Court of Strasbourg because it bans all corrections of personal data recorded at birth in the case of sex change, ended up adapting its own legislation to meet the European principles on non-discrimination.

An interesting aspect regarding this case-law is that in these cases the fundamental community rights impinge upon the regime of the British civil status, a subject certainly far from the Union's competence. The Court of Justice was asked to answer a question concerning the principle of non-discrimination on the basis of sex in the entitlement to survivor's pension and the definition of retirement age, but its decision ends up dealing with a matter that the member states did certainly not intend to transfer to the Community institutions, namely the legal status of transsexuals and the rules that govern the civil register.

As a matter of fact, in K.B. and Richards the European Court of Justice broadens the doctrine of incorporation. It is not necessary to insist here on this wellknown doctrine. ${ }^{18}$ Suffice to recall that up until now the area of application of fundamental rights, apart from being applied to the acts of the Community institutions, was also extended to the acts of the member states that cross the field of European law, and this happens in two main hypotheses: when the States' acts constitute an application of community law - the Wachauf line ${ }^{19}$ - and when the State act is an exception to one of the fundamental freedoms of the internal market - the ERT line. ${ }^{20}$

Now the K.B. and Richards cases obviously do not fall into either hypothesis. Censured British legislation does not constitute either rules of implementation or of execution of community acts; nor does it constitute an exception to the fundamental economic freedoms. As the Court of Justice states unequivocally, British legislation on the registering of personal data does not directly jeopardize a right protected by Community law - the right to the survivor's pension, but it has a discriminatory impact on one of the conditions necessary to the entitlement thereof.

It is too soon to say if a new 'spin-off' of the doctrine of incorporation has been heralded. However it is clear that in cases involving the non-discrimination principle, the European fundamental rights tend to break into the national legal orders, well be-

18 The first and fundamental essay about incorporation is J.H.H. Weiler, 'The European Court at a Croassroads: Community Human Rights and Member States Action', in F. Capotorti et al. (eds.), Du droit international au droit de l'integration. Liber amicorum Pierre Pescatore (Baden-Baden, Nomos 1987) p. 821 and on the recent evolutions of the incorporation principle see B. De Witte, 'The Past and Future Role of the European Court of Justice in the Protection of Human Rights', in P. Alston (ed.), The EU and Human Rights (Oxford, Oxford University Press 1999) p. 873.

19 ECJ 13 July 1989, Case 5/88, Wachauf.

${ }^{20}$ ECJ 18 June 1991, Case 260/89, Elliniki Radiopbonia Tielorassi ERT 
yond the limits of incorporation. This trend is evident for example in Tadao Maruko, ${ }^{21}$ a decision that asks the German legislation on same-sex partnership to be amended in order to grant the partners the same rights as spouses, at least as far as the right to pension is concerned. In many respects, this decision oversteps the boundaries between the national protection of fundamental rights and the European one. By consequence the Bundesverfassungsgericht as well as other German judges has reacted to the European Court decision, refusing to apply its interpretation. ${ }^{22}$

If this trend were to continue, the impact of Community law on the fundamental rights guaranteed by the national Constitutions would be dramatically broadened, toppling the limits to jurisdiction that were so carefully established in the Charter of Fundamental Rights, Article 51 and Article 53, according to the consolidated doctrine of incorporation. The risk involved in developing a fully-fledged incorporation in Europe modelled on the American experience is to trigger sharp constitutional conflicts with some member states and to homogenise European constitutional richness and variety into a single constitutional monologue.

\section{Cases on terrorism}

The Community institutions have often been accused of using different standards of protection of fundamental rights, depending on the nature of the question under review: generally speaking, the European Court of Justice seems to be much more demanding towards the member states (and even more so towards third-party States or States that are candidates for membership) and indulgent regarding the acts of the Community's institutions. In fact, the European Court of Justice case-law on fundamental rights is dotted with statements of principle but has rarely admitted a violation of rights on the part of the acts of the Community institutions, while it has more often ascertained violations on the part of the member states.

If we keep this context in mind, the importance of some cases on terrorism is unmistakeable. The decisions on terrorism regard some European Union Council regulations which, in executing UN resolutions, entail significant restrictions on people and associations that are reputed to be connected to terrorist networks. In all these cases, a number of violations of fundamental rights was claimed by the plaintiffs, including the violation of the right to property, the right to defence and the right to effective judicial remedy. The complaints originate from the fact that the lists of terrorists (or presumed terrorists) are compiled without permitting the subjects to explain their own reasons and thus without permitting them to refute the proof gathered against them.

21 ECJ 1 April 2008, C-267/06, Tadao Maruko, dealing with same-sex marriage and the right to the survivor's pension.

22 BVerf G, 6 May 2008, decision 2 BvR 1830/06. It has been argued that the Constitutional Courts of the new members of the EU are more reluctant to comply with the creative interpretations of the ECJ. See the interesting analysis W. Sadurski, 'Solange, chapter 3: Constitutional Courts in Central Europe Democracy - European Union', EUI Working Papers Law, n 2006/40 in http: //cadmus.eui.eu/dspace /bitstream/1814/6420/1/LAW-2006-40,pdf yisited 15 Jan. 2009. 
The CFI faced this problematic area in several cases, such as Yusuf and Kadi, ${ }^{23}$ Ayadi and Hassan ${ }^{24}$ and in the Modjahedines ${ }^{25}$ case providing different responses.

The first group of decisions caused some criticism, because it ended up sacrificing completely the plaintiffs' fundamental rights.

Starting with the Modjahedines case, the European judges appear more 'rightsoriented': in Modjahedines, the European Court declares the decision made by the European Union Council to be void for violation of fundamental rights such as the right to defence and the right to an effective judicial remedy. The Court relies on the fact that the inclusion of the plaintiffs in the list of terrorists was not done directly by the UN bodies but, on the contrary, by the European institutions, so that the Organisation des Modjahedines was harmed by virtue of a discretional choice of the European institutions. ${ }^{26}$ More recently, in Kadi, ${ }^{27}$ the European Court of Justice reversed a previous decision of the Court of First Instance and annulled some European Union Council regulations imposing restrictive measures against certain persons and entities associated with Usama Bin Laden, the Al-Qaeda network and the Taliban, for violation of fundamental rights - namely the right of defence - even though the European regulations had been issued in execution of UN resolutions.

The choices made by the Community's judges are certainly very courageous. Not only did the Court use the sanction of annulment of the contested acts, something that happens very rarely; but, of no lesser importance, the Community judges tested their capacity to be rigorous in the guarantee of rights on one of the prickliest terrains, given that the seriousness of the international situation tends to mitigate sensitivity to the rights of suspect terrorists and generates a greater propensity towards the need for security rather that towards that for justice and freedom. ${ }^{28}$

23 CFI 21 Sept. 2005, Case T-306/01, Yusuf; CFI 21 Sept. 2005, Case T-315/01, Kadi. For a deep analysis and criticism of these decisions see P. Eeckhout, 'Community Terrorism Listing, Fundamental Rights, and UN Security Council resolutions. In Search of the Right Fit', 3 EuConst (2007), p. 183 and C. Eckes, 'Judicial review of European Anti-Terrorism Measures - The Yusuf and Kadi Judgements of the Court of First Instance', 14 European Law Journal (2008), p. 74. See also a criticism to the content of jus cogens shaped by the CFI in C. Tomuschat, 'Note on Kadi', 43 Common Market Law Review (2005), p. 537.

${ }^{24}$ CFI 12 June 2006, Case T-253/02, Ayadi; CFI 12 June 2006, Case T-49/04, Hassan.

25 CFI 12 Dec. 2006, Case T-228/02, Organisation des Modjahedines du peuple d'Iran.

26 UN Security Council Resolution of 28 Sept. 2001, 1373 (2001). Council Decision 2 May 2002, 2002/334/CE and Council Decision 17 June 2002, 2002/460/CE both containing the name of the plaintiffs in the list of the suspected terrorists.

27 ECJ (Grand Chamber) 3 Sept. 2008, Case C-402/05P and C-415/05P, Kadi and Al Barakaat.

28 A thorough analysis of this case in the light of the relationship of the EU in the global context can be read in G. De Burca, 'The European Court of Justice and the International Legal Order after Kadi', Jean Monnet Working Paper 01/09, in http://www.jeanmonnetprogram.org/papers/ 09/090101.pdf at p. 21 et seq. 


\section{A panoramic overview}

If we consider the comprehensive result of this line of cases on fundamental rights, we cannot help remarking that something new has taken place in the European case-law since 2000. This panoramic overview of the recent case-law of the European Court of Justice on fundamental rights could continue ad infinitum, illustrating for example the consistent group of decisions regarding European citizenship or again illustrating the synergies which have over time been created with the protection of human rights guaranteed by the Court in Strasbourg and many others. ${ }^{29}$

Undoubtedly something is changing in the approach of the Court of Justice towards fundamental rights since 2000. Whoever observes at close quarters the European Court of Justice case-law today would answer affirmatively the challenging question posed many years ago: 'the European Court of Justice: taking rights seriously?' Today many decisions issued by the Community judges take fundamental rights extremely seriously. Since the approval of the Charter, plaintiffs and their lawyers use human rights more and more often as crucial legal arguments in the proceedings before the European court and these do not fail to speak the language of fundamental rights. Human rights, which in the past often seemed to be invoked as a mere rhetorical device, begin to affect the merits of the decisions of the European courts. In this development one cannot help but notice the powerful effect of the Charter of Fundamental Rights and the new 'visibility' of fundamental rights, which was precisely one of the purposes that the Charter intended to reach. Even though it still lacks an official legal status, the Charter has important spin-off judicial effects.

So, how can one not applaud a Court that shows it can occasionally sacrifice the needs of the economic freedoms in the face of human dignity, as happened in the Ome$g a$ case? How can one not admire the courage of a Court that stikes the organisation of the Modjahedines or Kadi from the list of terrorists in the name of their right to defence?

For sure, the European Court of Justice shows itself to be strongly committed towards a specific selection of rights - in particular towards the 'new rights' which are developing on the ground of non-discrimination and self-determination principles whereas its jurisprudence concerning other rights - and especially social rights - is generally considered as a disappointing one. ${ }^{30}$ However, all things considered, after the approval of the Charter, the feared effects of freezing and paralysing jurisdictional activism on the subject of fundamental rights did not occur; on the contrary, the result

${ }^{29}$ For a more complete analysis see M. Cartabia (ed.), I diritti in azione (Bologna, Il Mulino 2007). The problem is raised in L.B. and J.H.R, 'Editorial. The Relative Autonomy of the EU Human Rights Standard', 4 EuConst (2008), p. 199.

30 See for example L. Azoulai, 'Le rôle constitutionnel de la Cour de Justice des Communautés européennes tel qu'il se degage de sa jurisprudence', 44 Revue Trimestrielle de Droit Européen (2008), p. 29 , who emphasizes the constitutional role of the ECJ although criticizing its jurisprudence on social rights, in particular after decision 18 Dec. 2007, case C-341/05, Laval and decision 11 Dec. 2007, case C-438/3005, Viking. 
is the strengthening of the Court of Justice as a Court of Rights. It is probably for this reason that so many commentators now tend to define the European Court as a constitutional court. ${ }^{31}$ Today, several years after the approval of the Charter of Fundamental Rights, we can say without any shadow of a doubt that human rights are even more solidly in the hands of the Court of Justice and that the authority of this Court is becoming increasingly stronger.

\section{The Charter and the Court: legitimising effects, hermeneutical effects}

The Charter of Fundamental Rights seems to have strengthened the position of the Court of Justice from two aspects: on the one hand it has produced a legitimising effect and on the other a hermeneutical effect.

The Charter filled the void of written provisions on fundamental rights that had made the initial case-law of the European Court of Justice so sparing. The reference to fundamental rights provided in Article 6 in the TEU had not completely recovered the European Union from its initial weakness. The approval of the Charter offers a solid ground for the judicial protection of fundamental rights, indeed. ${ }^{32}$

Certainly, there is something paradoxical in the fact that the Charter is producing a legitimising effect on the Court although it has not (yet) any legal effect, ${ }^{33}$ but is in fact merely a political statement. However, the fact that since immediately after its proclamation the Charter of Fundamental Rights has been invoked and applied by many national judges, including many national constitutional courts, as well as appearing regularly in the decisions of the Court of First Instance and in the Opinions of the Advocates-General, has created an aura of legality around the document, explaining the potential of legitimisation that it has produced also as regards the Court of justice.

Moreover, the Commission, the European Parliament and the Fundamental Rights Agency regularly refer to the Charter as if it were a legally binding document.

Even more striking are the hermeneutical effects of the Charter of Fundamental Rights.

Generally speaking every legal written text should serve to limit room for interpretation on the part of judges. This, at least, is the concept that has been spread by the multi-secular tradition of civil law countries since the French revolution. The legal systems in continental Europe, for right or for wrong, have been inspired by the idea

31 See supra n. 2.

32 Previously, the role of the Court of Justice as guarantor of rights was undermined by the lack of a text able to reflect, for better or for worse, the constitutional identity shared in the European Community. M. Rosenfeld, 'Comparing constitutional review by the European Court of Justice and the U.S. Supreme Court', 4 International Journal of Constitutional Law (2006), p. 618.

33 The Charter will be provided of legal effects if the Treaty of Lisbon enters into force, because it contains an amendment of Art. 6 of the TEU, which reads: 'The Union recognises the rights, freedoms and principles set out in the Charter of Fundamental Rights of 7 December 2000, as adapted on [... 2007], which shall have the same legal valie as the Treaties.' 
that judges are the 'bouches de la loi' 34 and that their mission is to say what the written law provides, and to apply it to the specific cases brought before them. And yet, the Charter does not seem to have limited the creativity of the Court of Justice but rather seems to have produced quite the opposite result.

This paradoxical effect can be explained under several respects.

First and foremost, it needs to be considered that the goal of reducing the role of judicial power by means of the written law has not been achieved, not even in the national systems that follow the tradition of civil law. History has extensively shown that jurisdictional activity cannot be reduced to the mechanical application of the law in the form of judicial syllogism, and in recent years the role of judges is becoming all the more relevant, in particular in fields related to fundamental rights. 35

Moreover, it needs to be considered that the Charter of Fundamental Rights operates in a 'multi-level' system, where it is placed alongside many other 'bills of rights', such as the 27 national Constitutions, the European Convention of Human Rights, a wide range of unwritten constitutional principles elaborated by all the high courts that deal with human rights and especially by the Courts in Luxembourg and Strasbourg. As is well-known, in the systems of common law ${ }^{36 j u d g e s ~ e n j o y ~ a ~ w i d e ~ d i s c r e t i o n a r y ~ p o w-~}$ er for the simple fact that in order to solve a case or controversy they can take into account many different sources of law. In fact, one of the main reasons that explains the extent of the discretionary power of judges in the systems of common law is the possibility that they have the opportunity to refer to a multiplicity of competing sources of law in exercising judicial review. The habit of judges to recall foreign law and international law in cases involving fundamental rights adds further options to their discretionary power.

Lastly, it must also be considered that the text of the Charter is, so to speak, loosely formulated. The language of the Charter is very general and by consequence it does not provide strict guidelines for its interpreters. In order to find a satisfactory compromise for all the member states, the Charter uses a very broad wording, limiting itself to codifying principles and basic values which are generally shared, postponing the more controversial issues to a more detailed legal regulation or to the discretionary power of judges. Let us consider some of the provisions of the Charter: 'Human dignity is inviolable. It must be respected and protected', 'Everyone has the right to life', 'Everyone has the right to his or her own physical and mental integrity', 'Everyone has the right to freedom and security', 'Everyone has the right to respect for his or her own private and

34 For a critical historical overview of this principle, see K.M. Schönfeld, 'Rex, Lex, Judex', 4 European Constitutional Law Review (2008), p. 274.

35 For the Italian experience see E. Lamarque, 'L'attuazione giudiziaria dei diritti costituzionali', Quaderni costituzionali (2008), p. 266, who shows the creation of an impressive number of new fundamental rights by means of judicial decisions stating on requests of compensations for damages.

36 See in particular on this point M. Rosenfeld, 'Constitutional adjudication in Europe and in the United States: paradoxes and contrasts', 2 International Journal of Constitutional Law (2004), p. 633 at p. 646. 
family life'. Faced with such a text, all the interpretative options lie wide open and the discretionary power of the interpreter plays a most important part.

For all these reasons, far from paralysing jurisdictional creativity, the introduction of the Charter of Fundamental Rights is further increasing the power of the Community judges, who have always been a vital engine for the development of European integration.

\section{The risk of 'judicial colonialism'...}

As does every relevant change, the new trend in the European Court of Justice case-law entails both advantages and disadvantages. In particular, the judicial activism in the field of fundamental rights brings about new assets but also some concern for the constitutional equilibrium between the European Union and the member states, and more importantly - for the survival of the diverse historical traditions entrenched in the national constitutions, which are part and parcel of the European identity. I do not want to insist on the risk of the gouvernement des juges, although it is clearly implied in the present phase of European integration. I would rather draw the attention to a different concern that I would call, with some intentional emphasis, 'judicial colonialism'.

It could be easily predicted that the approval of the Charter of Fundamental Rights would produce a centralising effect, gradually drawing the protection of human rights to the European level and at the same time sterilising the protection guaranteed by the national Constitutions and breaking the limits of jurisdiction in which the action of the Community institutions should be carried out. ${ }^{37}$ In this centralising movement, the national constitutional traditions risk to be extinguished.

Cases like K.B., Richards, and Tadao Maruko are unquestionable examples of the invasion of the Community's protection of fundamental rights into areas where the responsibility should lie with the national Constitutions. Article 51 of the Charter and the principles of incorporation 38 limit the European judicial review on national acts only to cases where 'the member states are implementing Union law'. In those cases the member states were not implementing EU law. All this considered, why should the Court of Justice be involved in the violations of transsexuals' rights in the British system? The problem was under control; in particular it was under the supervision of the British courts and the Strasbourg Court. ${ }^{39}$ Cases like K.B., Richards and Tadao Maruko widen the scope of the European Court of Justice judicial review on states' legislation well beyond the limits of the incorporation. Besides this, as the Kreil case shows, this

37 A. von Bogdandy, 'The European Union as a Human Rights Organization?', supra n. 3, at p. 1316-1318. See also on this point A.C. Pereira-Menaut, 'A Plea for a compound res publica europea: proposal for increasing constitutionalism without increasing statism', in Tulane European and Civil Law Forum (2003), p. 75 at p. 97-98.

38 See supra $\mathrm{n} .17$.

39 After all, the European Court of Human Rights of Strasbourg in Goodwin v. United Kingdom, 11 July 2002, 28957/1995 had already issued a judgment against the United Kingdom for its legislation on the transsexuals. 
expansion can also impinge upon the national constitutions. The Charter was conceived with a limited scope, addressing essentially the Community institutions and the national institutions only when they execute Community law. Nonetheless, the Charter tends to be treated as if it were to overcome the national constitutions. As has been pointed out, ${ }^{40}$ one of the most difficult tasks is to explain that the Charter was not intended to take the place of national constitutions.

The expansion of the scope of fundamental Community rights is not only a matter of jurisdiction - the role of the Court of Justice that takes over responsibilities of the national Courts - but also a tricky question on the substance of the protection of fundamental rights, because it could happen that the Community's 'version' of some rights does not correspond entirely to that of one or more member states: after all, the European Union endorses an individualistic/libertarian interpretation, whereas many national constitutions are oriented to a personalistic/dignitarian conception of fundamental rights. ${ }^{41}$ As has been recently pointed out, the European Union talk on fundamental rights has put the individual in the centre, but it is a self-centred individual; 42 whereas for example, the Italian Constitution is inspired by the second line of thought, starting with its Article 2: 'The Republic recognizes and guarantees the rights of each human being considered both as an individual and within the intermediate social bodies where his/her personality flourishes.' The expansion of the Community's protection of rights may end up having an impact on those fields where the national particularity is unquestionable.

The fact that cases like K.B., Richards, Kreil and others have generally been supported by public opinion and commentators must not cloud the transformation that is occurring in the relationships between the Community's system and the national constitutional systems in the protection of fundamental rights. By endorsing such developments one must be aware that they leave themselves open to being used in controversial cases, where the divergence between the national constitutions and the European principles can be more striking. ${ }^{43}$ Questions which are ethically controversial in the field of fundamental rights, albeit regarding problems common to every human being, have received and still receive different answers in different countries. The questions that concern the coexistence of different cultures - and first and foremost those related to the freedom of religion - concern everyone and arise in every social group, and yet they

40 F.G. Jacobs, European Convention of Human Rights, 'The EU Charter on fundamental Rights and the European Court of Justice', in http://www.ecln.net/elements/conferences/book_berlin/ jacobs.pdf visited 29 Jan. 2009.

41 On the interpretation of these two lines see M.A. Glendon, 'Human Rights at the Dawn of the Third Millennium', in L. Antonini (ed.), Il traffico dei diritti insaziabili (Cosenza, Rubbettino 2007), p. 45 .

42 J.H.H. Weiler, Europe - Nous coalisons des Etats, nous n'unissons pas des hommes, forthcoming

43 See on this point the critique to the multilevel constitutionalism - because of the fact that it hides the conflict between legal systems - by M. Luciani, Costituzionalismo irenico e costituzionalismo polemico, in http://www.associazionedeicostituzionalisti.it/materiali/anticipazioni/costituzio_nalismo_irenico/index.htm 1 visited 29 Jan. 2009, p. 25. 
have found different answers in the course of history and even today are dealt with according to particular traditions in each of the European systems. ${ }^{44}$

Most cases brought before the European Court of Justice concern vulnerable subjects such as women and migrant workers and understandably the Court wants to accomplish its own constitutional mission towards them. However, in most member states of the European Union, problems related to sexual orientation, same-sex marriage, abortion, bioethics issues, immigration and the like, mark deep cultural and political cleavages and are usually dealt with very carefully in order to find balanced solutions that reconcile the different points of view at stake. The European Court of Justice has taken over its own 'judicial policy' in favour of women, immigrants, homosexuals, transsexuals and in general of all the vulnerable subjects. The Court does not even hesitate to impose dramatic changes in the member states' policies and legislation. The result is that diverse cultures and traditions on these subjects are receding to give room to the European constitutional standard fostered by the European Court of Justice.

The practical effects of the Charter of Fundamental Rights as interpreted by judges are supported by a widespread legal thought that fosters the development of common European values - a 'jus commune europeum'. ${ }^{45}$ This implies the idea that the whole continent can be unified around universally shared values and that unification flows from the judges' pens. ${ }^{46}$ While the political and economical European Union is going through a phase of stagnation, the Europe of judges and rights looks vigorous and dynamic. The success of the Europe of judges and rights is at least partly due to the opinion that the European - and more generally - the international institutions seem to be located at a more suitable level for the protection of fundamental rights. Fundamental rights are pulled out of the local boundaries, because they have a universal core: human dignity. That is why the protection of fundamental rights seems to fit better in the international scene rather than in national or local communities. The multicultural societies are in the middle of the dramatic and urgent quest for unity and for a common ground of values for all cultures. The most common and shared opinion is that human rights can provide an answer to this quest. Given the universal nature of fundamental rights, European law and international law are taking the place that used to be occupied by natural law, since they imply the idea of a core of values and rights common to all human beings.

44 See the analysis of J.H.H. Weiler, Un'Europa cristiana (Milano, Rizzoli 2003), showing the different relationship in Europe between the public power and religion.

45 We can consider the origin of this line of thought to be I. Pernice, 'Multilevel Constitutionalism in the European Union', quoted supra n. 7, p. 511. In Italy see at least G. Silvestri, 'Verso uno ius comune europeo dei diritti fondamentali', Quaderni costituzionali (2006), p. 7; A. Pizzorusso, Il patrimonio costituzionale europeo (Bologna, Il Mulino 2002); V. Onida, 'Armonia tra diversi e problemi aperti', Quaderni costituzionali (2002) p. 549.

46 For insight on the American debate about the aristocratic and paternalistic character of judgemade law see A. Gutmann (ed.), A Matter of Interpretation (Princeton, Princeton University Press 1997) in particular the Comment to Justice A. Scalia by M.A. Glendon, p. 95. 
We must not, however, forget the ambivalent nature of fundamental rights. In the struggle for fundamental rights there is a longing for universality that justifies the need to go beyond the boundaries of the national legal systems; but there is also a historical dimension in which the traditions and deepest conscience of each people is reflected, of which the national constitutional charters are one of the salient expressions. Rooted in the value of human dignity, the idea of fundamental rights necessarily contains a universal dimension. Embedded in the historical, religious, moral, linguistic and political peculiarities of each people, such rights are fed by particularity and pluralism. ${ }^{47}$

The attraction to a European protection of human rights risks sacrificing the national historical and cultural traditions that characterise the pluralistic nature of Europe. Even more serious: what happens if one of the fundamental rights protected at the European and international level belongs only to one or some specific traditions or cultures and does not reflect any common shared value? Who will guarantee that the European and the international institutions will stick to the protection of the common fundamental rights and are not tempted to impose a particular interpretation of them as if it were universal?

The position of the Court of Justice is crucial and extremely delicate. Its pronouncements on the subject of fundamental rights tend to establish the standard that must be respected throughout the 27 countries of the Union. 48 Once a fundamental right enters the jurisdiction of the Court of Justice it becomes a European fundamental right. The decisions taken by the Court of Justice are binding in all the member states even if the case originated in a particular legal system.

Herein lies the risk of 'judicial colonialism' in the field of fundamental rights. As history has shown us, colonialism often claims to promote progress and civilisation, but on more than one occasion pre-existing cultural and historical patrimonies have been sacrificed in the name of a specific culture, although more progressive. Fostering fundamental rights is indeed a clear sign of progress and civilization. But, what about the native cultures and traditions of the European peoples? And how can a society be able to welcome and respect the cultures of immigrant peoples if it proves to be unable to take care of its own historical patrimony and diversity?

As has been highlighted, the very nature of the European Union is that of a pluralistic, tolerant, multiple, 'contra-punctual' legal order, ${ }^{49}$ where a plurality of voices tends to harmonisation. Should the European Union move towards a uniform standard in the field of fundamental rights, trampling on the plurality of national constitutional traditions, then it would betray its own ontological structure.

47 P.G. Carozza, 'Uses and misuses of comparative law in international human rights', 74 Notre Dame Law Review (1998), p. 1235.

48 This effect is clearly grasped in S. Panunzio, I diritti fondamentali e le Corti in Europa (Napoli, Jovene 2005), p. 58.

49 See supra nn. $4,5,6$. 


\section{... and its antidote: a common basic experience}

This risk needs to be faced with an effective antidote. It is difficult to elaborate the complete recipe of it, but some of its components can already be singled out. Here I would like to highlight two essential elements. First, every new fundamental right should be recognised only if is part of a common basic experience throughout the whole European continent; second, the common experience cannot be defined in a dogmatic style, in abstracts formulas or written principles. Fundamental rights are living concepts that can only emerge from the live encounter among different peoples, each one having its own tradition, history and culture. The method should not be deductive, but rather inductive and it requires a bottom-up dynamic. Indeed, the common basic rights of the European Union have been identified and codified in the Charter of Fundamental Rights. Nevertheless, the meaning of those rights is constantly being reshaped in order to cope with new social problems and new judicial cases. Social life is dynamic and history never stops. So, whenever written rights impact real issues, their content tends to broaden and sometimes 'new fundamental rights' are deducted as spin-offs of the older rights. In recent years, several new rights have been carved out from privacy and from antidiscrimination clauses, for example.

This evolution is in some way inescapable. Moreover it is commendable under many respects. Nonetheless, in a composite polis such as the European Union it also discloses some downsides. As a matter of fact, in the European context, every new right is a potential cause of tension with the multiple constitutional traditions of the European countries. In order to prevent the extinction of the existing constitutional traditions, the number of fundamental rights should not be excessively widened and, what is more relevant, every 'new fundamental right' should dovetail with the living experience ${ }^{50}$ of European peoples.

To this purpose we should look beyond the texts. Constitutional and legal documents on fundamental rights very often repeat similar formulas, in many different countries in and outside Europe. However, historical, cultural and social contexts change, so that different peoples have a different experience of the same fundamental rights. That is why similar legal concepts - such as human dignity, equality, freedom, etc. - can assume different meanings in different contexts. Diversity in the field of fundamental rights cannot easily be divined from texts. It is rather a matter of experience.

So the farther away we get from the core of fundamental rights, the greater the historical and cultural divergence between the various juridical systems may be. This is the reason why the proliferation of 'fundamental rights' may impair the constitutional balance of the whole Union. The jus commune europeum or, if you like, the 'common

50 The idea of legal experience can be read in G. Capograssi, Analisi dell'esperienza commune (Milano, Giuffré 1975) and in the same line of thought P. Grossi, Società, diritto, stato: un recupero per il diritto (Milano, Giuffré 2006), who draws the attention to the historical and cultural character of the law, beyond legal positivism. 
constitutional traditions' are undoubtedly a reality recognisable around a consolidated and limited nucleus of values, while the category becomes more uncertain and shaky the farther one strays from that essential nucleus of common values. Great care must be taken when recognising 'new fundamental rights' at European level. The wider the scope of activity of a human rights institution is, the closer it should stick to the common basic experience of the peoples falling within its jurisdiction. Many new social needs and desires can be answered by means of legislative measures, taken at the national or supranational level, rather than by means of new fundamental rights. After all, the primary task of the Courts is to guarantee the existing fundamental rights rather than create new ones.

But here a crucial question arises: how can the common rights be recognised? Or, if you want, how can we draw a distinction between common European basic rights and further rights belonging to a specific culture or to a particular group? This question is a crucial one, in order to ensure to all human persons all the fundamental rights that they deserve as human beings, without imposing on anybody any political or cultural preference under the name of fundamental rights.

Here I would like only to make a methodological remark. The common core of different cultures and traditions stems from the encounter among living subjects able to express them. No centralised institution can take the place of the European peoples, nor can it act on behalf of them. The active participation of the bearers of the different traditions is unavoidable. Comparing legal and judicial texts is necessary, but not enough, because the living meaning of fundamental rights develops within the experience of each people. The comparative method is to be completed by the active participation of all the stakeholders.

The commitment to universal fundamental rights does not require the homogenisation of the existing diversities, but - on the contrary - requires that they be taken extremely seriously. Universality does not imply erasing differences, but it results from the encounter between them. After all, human rights relate to human beings, not to humanity. ${ }^{51}$ So they can only be recognised in the historical experience of peoples. That is why all the subjects that can express a specific tradition should be active parts of the European constitutional construction: social groups, legislators, judges, public authorities. In a certain sense, the European motto could read 'unity from living diversity'.

\section{The role of judiciary: reasons for intensifying the constitutional conversations on fundamental rights}

The method outlined above involves many different kinds of agents. Democratic institutions, agencies, NGOs, all sorts of social subjects are required to become effective agents of a living culture of fundamental rights in Europe. Still a distinguished task rests on judges.

51 P.G. Carozza, 'Human Dignity and Judicial Interpretation of Human Rights', 19 The European Journal of International Law (2008), p 931. 
As far as the judiciary is concerned, the destiny of the national cultural traditions in Europe is in the first place entrusted to the constitutional courts, which express the voice of the national constitutions. They are the privileged interpreters of the national constitutions, they are viva vox constitutionis. 52 The European Court of Justice bases its work on the voices and traditions that make themselves heard, and if one voice is missing, the cultural patrimony of the whole of Europe is diminished. Only if the constitutional courts are able to interpret and proudly express the peculiarities of their own constitutional traditions will the Court of Justice be able to identify the 'common constitutional traditions' and the common core of European fundamental rights. On the other hand, the Court of Justice is to show great respect for all the national constitutional traditions when interpreting and applying the principles of the European Union Charter of Fundamental Rights.

The European legal system provides a procedural tool that can greatly help this difficult enterprise: the preliminary ruling ex Article 234 EC.

The Italian Constitutional Court has recently taken a step worth noting: in decision n. 103 of $2008^{53}$ the Court has used the preliminary ruling for the first time ever. This decision shows a new co-operative attitude of the Constitutional Court towards the European Court of Justice, an attitude which overrules decision n. 536 of 1995, when the Court refused, even from a theoretical point of view, to enter into direct dialogue with the European judges. For years the Italian Constitutional Court has urged the lower courts to use the preliminary ruling while excluding itself from the European judicial dialogue. The official reason for the exclusion was that a Constitutional Court plays functions that are not jurisdictional in nature, and therefore the Constitutional Court cannot be qualified as a judge for the purpose of Article 234 EC. The new trend started in 2008 overrules these general principles. However, the overruling should not be overemphasised. In decision n. 103 of 2008 the Constitutional Court has opened the dialogue within a specific kind of proceedings, the so-called 'direct proceedings' concerning the division of competences between state and regions. The Court draws a clear distinction between the 'direct proceedings' and the 'indirect proceedings' for the purposes of the preliminary rulings of Article 234 TEC. Most commentators ${ }^{54}$ share the idea that the Constitutional Court wants to limit the use of the preliminary ruling only in 'direct proceedings', whereas in 'indirect proceedings' it should be for the lower courts to ask for the European Court's interpretations. Should the Constitutional Court follow this restrictive interpretation, then the judicial dialogue with the European Court would not be likely to touch the most sensitive issues of constitutional law. As a matter fré).

52 V. Onida and B. Randazzo (eds.), Viva vox constitutionis, annual series since 2002 (Milano, Giuf-

53 All the Italian Constitutional Court's decisions can be found at www.cortecostituzionale.it and www.giurcost.org visited 29 Jan. 2009.

54 This interpretation is endorsed for example by M. Dani, 'Tracking Judicial Dialogue - The Scope for preliminary Rulings from the Italian Constitutional Court', Jean Monnet Working Paper 10/ 08, in http://www.jeanmonnetprogram.org/papers/08/081001.pdf yisited 15 Jan. 2009 
of fact, in 'direct proceedings' the Court does not usually deal with fundamental rights, but only with matters of competences. That is why at present it is hardly predictable whether Italy will abandon its traditional reluctance to contribute to the European construction of fundamental rights. To be true, most of the national constitutional courts maintain a haughty contempt towards the European Court of Justice: they refuse to enter into direct dialogue; in particular they refuse to use the preliminary ruling provided by Article $234 \mathrm{EC}$ (and Article $35 \mathrm{EU}$ ). In fact, up to now, only the British House of Lords, the Belgian Cour d'arbitrage and the Austrian Verfassungsgericht have referred to the European Court of Justice by means of preliminary rulings. ${ }^{55}$ The Polish Constitutional Tribunal has accepted 56 the possibility of addressing the European Court, but has not yet used it in practice. All the other constitutional courts keep strictly silent on the European stage. Usually, the national constitutional courts accept the informal influence of the European Court of Justice's jurisprudence, but they distrust the formal judicial dialogue through the preliminary ruling. 57

As has been said, the rights talk in the European Union system is becoming more and more relevant and the participation of the national constitutional courts more urgent. Both the national constitutional systems and the European constitutional systems could pay too high a price if their courts shut themselves out of the European constitutional dialogue, the former being deprived of the possibility to express themselves in the European arena, and the latter losing one or more of their contributions.

In this light we need to consider that the preliminary ruling could be a valid tool in bringing traditions, experience, reasoning and different points of view before the Court of Justice on the part of the national constitutional courts. In short, it is the simplest way to keep pluralism alive within the European constitution. Although following the wording of Article 234, the preliminary ruling is conceived as a duty and an obligation for the supreme courts, it is, in fact, above all a great opportunity for them. It is shortsighted to refuse the preliminary ruling for fear of losing freedom, sovereignty and independence. The bright side is that the preliminary ruling is a great chance for national judges to take part in the building up of the European constitution. If the constitutional courts refuse direct dialogue with the European Court of Justice, they miss the opportunity to have any influence on the European decisions. Indeed, the European Court of Justice is open to take into account all the national constitutional traditions coming from the member states. But these traditions need to be introduced before it. Otherwise how could the European Court be aware of a particular constitutional principle? In a way a constitutional court using the preliminary ruling could be considered as a qualified 'amicus curiae' of the Court, bringing arguments useful for the decision.

55 See the annual reports of the European Court of Justice available at http://curia.europa.eu/ en/instit/presentationfr/index.htm visited 29 Jan. 2009.

56 Polish Constitutional Tribunal 11 May 2005, K 18/04. par. 18.

57 A critique to the informal relations among European courts as a part of a more general critique to the pluralist model of relationship in the European Union comes from J. Baquero Cruz, 'The Legacy of Maastricht Urteil and the Pluralist Movement', 14 European Law Journal (2008), p. 389 at p. 414. 
The specific mission of the constitutional courts does not only imply the defence of the constitutional values when they are attacked, but also to promote them as a necessary part of the construction of Europe.

Moreover, the European Court of Justice would gain greater authority if it had the opportunity to benefit from the rich constitutional experience of the national constitutional courts. As has been pointed out in an interesting comparison between the US Supreme Court and the Luxemburg Court, 58 whereas the Supreme Court 'has the benefit of the many judicial decisions by low federal courts and/or state courts on constitutional issues it must decide upon', the European Court of Justice, by contrast, 'cannot count on the experience of the other courts', because it does not decide on appeal. This comment is very important insofar as it highlights that one of the main advantages of the common law system is that it is based on an inductive, incremental and empirical process where the Supreme Court decides after a number of previous decisions by lower courts. This is all the more important in constitutional adjudication, where delicate choices of value are often at stake. It is of crucial importance for the European Court of Justice to take into serious consideration the different solutions offered by other national courts before settling delicate and sometimes politically explosive constitutional issues. Although the European Court of Justice, compared with the US Supreme Court, decides without the experience of the lower courts, ${ }^{59}$ the preliminary ruling could heal at least in part the deficit of experience. The preliminary ruling could serve the purpose of presenting rich and diverse points of view before the European Court. One of its functions could be precisely to bring experience to the European Court, linking its judgments to concrete cases pending before the national tribunals.

Some constitutional courts seem to have sensed that an historic task is incumbent on them. It is indeed certain that the Conseil constitutionnel has understood this, as shown in its decision on the European Constitutional Treaty, ${ }^{60}$ where it endorsed some interpretations of the Treaty on the subject of linguistic minorities and religious freedom which deliberately wanted to stretch the meaning of the text so as to ensure that the application of the principles would conform with the French tradition. It is not by mere chance that recently the Conseil has wanted to speak explicitly of the 'French constitutional identity' in its decision on the subject of copyright royalties. ${ }^{61}$ With these decisions regarding its relationship with the European Union, the Conseil shows how it is able to propose the French constitutional tradition as an interpretative hypothesis for the European constitutional principles and place itself as an authoritative, strong inter-

58 M. Rosenfeld, 'Comparing constitutional review by the European Court of Justice and the U.S. Supreme Court', quoted supra at n. 35, p. 628.

59 Ibid., p. 629-630.

60 Decision 19 Nov. 2004, n. 2004-505 DC, Traité établissant une Constitution pour l'Europe.

61 Decision 27 July 2006, n. 2006-540 DC, Considérant 19 : « la transposition d'une directive ne saurait aller à l'encontre d'une règle ou d'un principe inhérent à l'identité constitutionnelle de la France, sauf à ce que le constituant $\mathrm{y}$ ait consenti 次 
locutor for the Court of Justice in Luxembourg, called upon to bring to life common constitutional values.

The Conseil constitutionnel seems to foresee the risk that the particular features of the national constitution dissolve into the work of harmonisation carried out by the Court of Justice. The antidote that can and must be activated to contrast the germs of a potential risk of constitutional homogenisation is in the hands of the national constitutional judges, if they are able to convey the constitutional tradition of their own legal order to the central institutions for the common good of the whole society. Otherwise, the constitutional courts are condemned to accept a cultural homogenisation established by the strongest voices, or to fight a sterile battle of defence, entrenched behind national sovereignty. The remedy is not isolation in sovereignty, but participation.

It is on this backdrop that we have to assess the need to rethink the choices made by the constitutional courts on the preliminary ruling. At stake is not only the correct application of a procedural tool, but rather more significantly it is the opportunity for the national constitutions to have a voice in Europe; the use of the preliminary ruling could have a constructive value in the European constitutional foundation.

\section{Taking dialogue seriously: the role of the European Court of Justice}

As has been insisted on in the previous pages, the very nature of the European constitution or - might I even dare to say - the very nature of Europe itself, requires a lively participation of all the plurality of voices, traditions and historical experiences which altogether are part and parcel of the European identity. It is not only in the interest of a particular national tradition that the constitutional conversation on the European values and fundamental rights is to be kept alive. It is also of vital importance for the European Union to encourage and support the participation of all its components, in order to be faithful to its own origin and structure. As has been argued:

Europe's basic Constitutional Architecture [...] was noble and original, fashioned in accordance with Schumann's astute step by step approach in a remarkable consensual multilogue among Europe's courts, high and low. This collaborative judicial-political exercise was not only procedural expedient, it was a reflection of Europe's substantive Grundnorm and its most striking contribution to transnational statecraft: the principle of Constitutional Tolerance. 62

This is the reason why the European Court of Justice cannot afford to allow the constitutional conversation to flag. It is vital for its own mission to do its best to keep the 'multilogue' alive.

So, if we consider the decisions of the European Court on their merits, there is no doubt that in general, the Court shows deference and respect towards the constitutional traditions of the member states present in the judicial process. Cases like Omega and

62 J.H.H. Weiler, 'The essential (and would-be essential) jurisprudence of the European Court of Justice: lights and shadows too', in I. Pernice, J. Kokott, C. Saunders (eds.), The Future of the European Judicial System in a Comparative Perspektive (Baden-Baden, Nomos 2006), p 117. 
Schmidberger show that the European Court has taken the German and the Austrian constitutional traditions very seriously. However, one question needs to be answered. What about the other constitutional traditions? Are we sure that all the voices have been expressed before the Court so that the final decision really takes into account the entire common background of the European countries? Are we sure, for example, that the meaning given by the European Court of Justice to human dignity in Omega is really shared by the European member states other than Germany? Or does it reflect the specific sensitivity of the German constitution? If the European Court wants to be the Court of the European citizens, it should be very careful not to issue decisions which are too nationally oriented, i.e., decisions that elevate to the rank of fundamental human rights a particular interpretation of a basic value, accorded in a specific country due to its history and tradition.

I have already insisted that there is no justification for the national constitutional courts' behaviour of remaining aloof from the European constitutional multilogue. I would like here to argue that also the European Court of Justice bears part of the responsibility for the national constitutional courts' silence for two main reasons.

First, it is not just the national courts' fault that the European judicial multilogue has been developed mainly among the lower courts and the European Court of Justice to the exclusion of the supreme and constitutional courts. The Simmenthal doctrine has given great importance to the lower courts, and has induced the higher courts - in particular the constitutional courts - to stay removed from European legal evolution. It is true, as has been said, that the European constitutional architecture was not fashioned by the European Court of Justice alone, but by all the European courts, the national courts included. It is true that

the European Court has historically been quite attentive to position itself as primus inter pares [... and] to fashion its doctrines so as to empower national courts as its principal and indispensable interlocutors. ${ }^{63}$

However, this is particularly true for the lower courts. It is the lower courts that have taken advantage of the European Court doctrines, even to the detriment of the national supreme and constitutional courts. Doctrines like supremacy, direct effect, indirect effect and many others are powerful tools for the judicial activity of lower courts, which have been freed by the European Court from the narrow role of bouches de la loi and elevated to a constitutional mission. The result is a sort of marginalisation of the constitutional courts from the European constitutional laboratory. It was probably necessary at the beginning of European integration to give the lower courts the main responsibility of enforcing European law; however one could pose the question as to whether is it still necessary at the present stage, focused on the fundamental rights talk, to continue to treat the lower courts as the most qualified actors of the judicial architecture of the European Union. Doctrines like direct and indirect effect could easily be

63 J.H.H. Weiler, 'The essential (and would-be essential) jurisprudence of the European Court of Justice: lights and shadows too' guoted supra at n. 6. p. 121. 
interpreted so as to involve also the supreme and constitutional courts, instead of banning them.

Second, if we consider the style and the form of the decisions of the European Court of Justice, more than one doubt arises regarding its attitude towards the national constitutional courts and towards their participation in the European adventure. As was said in a sharp critique of the European Court: 'the style of judicial decisions is outmoded, does not reflect the dialogical nature of European Constitutionalism, and is not a basis for confidence building European constitutional relations between the European Court and its national constitutional counterparts.' ${ }^{\prime} 4$ The problem with the style of the European Court of Justice decisions is not only aesthetic in nature. After all, one of the specific characteristic of the European system is that the more relevant constitutional steps in the European development depended upon the co-operation of the European and national institutions. Trust and mutual confidence between the European Court and the national Courts are the bases of the whole European Constitution. That is why, when the European Court takes decisions on fundamental rights which often involve the most important, delicate and controversial constitutional issues, 'it is critical that such decisions emanate from a tribunal which is capable, and seen to be capable of comprehending the constitutional sensibilities of the member states at issue and communicating that comprehension to its national counterparts.' 65 The problem is not only that the European Court takes into account the national constitutional peculiarities, but also that it shows it has considered and discussed those peculiarities. In the European Court decisions the national court which applied for the preliminary ruling looks for feedback to its arguments and deserves such feedback. Why, otherwise, should a national court spend time and effort working out its own national constitutional tradition for the benefit of the European institutions if they do not show they attach any weight to such work? The first reason why the European Court of Justice should - as Joseph Weiler suggests - abandon its Cartesian style of judgments and move to a more discursive and conversational style, typical of the common law countries, is precisely to encourage the constitutional dialogue with the national supreme and constitutional courts.

There is a second, and perhaps more relevant reason for such a move. This reason is a direct consequence of a recent, important and widespread evolution in constitutional judicial review. Although the main purpose of the judicial review was at the origin and still is to decide on the validity of normative acts, nowadays the judicial activity is more and more focused on interpretation. It is quite rare that a constitutional court decides for annulment or declares the invalidity of a piece of legislation. In most cases, the constitutional courts try to accommodate cases and controversies by means of interpretation. This is true both at national and European level. In all the legal systems the core of the judicial activity is shifting to interpretation, and judges are required to be well-equipped in ars interpretandi even more then in ars decidendi. At the national

64 J.H.H. Weiler, 'Epilogue: The Judicial Après Nice', in G. De Burca and J.H.H. Weiler (eds.), The European Court of Justice (Oxford, Oxford University Press 2001), p. 219.

65 J.H.H. Weiler, 'Epilogue: The Judicial A.près Nice', quoted supra at n, 63, p. 221. 
level it is sufficient to consider the importance attached to the so-called 'interpretazione conforme a Costituzione' or 'verfassungskonforme Gesetzauslegung' in Italy and Germany as a way of solving all sorts of clashes among different legal acts; 66 at the European level suffice it to notice that it is probably not by mere chance that the preliminary ruling of Article 234 of the TEC is by and large more used for interpretative questions, rather than for challenging the validity of the Community acts. No doubt that hermeneutics is the fundamental tool of relationship between different levels of legislation and, by consequence, between different types of courts.

The most recent trend in judicial activity shows that conflictual remedies leave room for harmonising remedies. This is true in general, but it is particularly true when constitutional issues are at stake, such as in cases involving fundamental rights. Constitutional principles are worded in such a loose and general way that is it difficult even to imagine a direct clash between a national Constitutional provision and a European one. On the other hand, it is not so difficult to imagine a conflict of interpretation of such provisions between different courts. That is to say that problems do not arise from the texts, generally speaking; more often they arise from the interpretation of the texts in judicial cases.

That is why the European Court, especially when acting as a constitutional court or a court of fundamental rights, should seriously consider moving away from the oldstyle telegraphic judgments, although this style is endowed with important virtues: it not time-consuming for the judge who writes the decision of the Court and for the translators and, moreover, it can facilitate the compromise among different points of view, easily leading the Court towards its final decision. However important these practical reasons may be, more relevant is that the European Court needs to be engaged in a continuous conversation with its national counterparts, especially in constitutional cases involving fundamental rights.

The historical changes that are occurring in the European Union and that involve the very basis of European society require a new attitude on the part of all the actors. ${ }^{67}$ In the present constitutional era of the European Union, 'taking dialogue seriously' is an imperative for both the European and the national constitutional courts. Most of the

66 See D. Schefold, 'L'interpretazione conforme a costituzione', in http://www.associazione deicostituzionalisti.it/materiali/convegni/aic200610/schefold.html visited 29 Jan. 2009 www.associazio nedeicostituzionalisti.it; M. Luciani, 'Le funzioni sistemiche della Corte costituzionale oggi e l'interpretazione 'conforme a', Il foro amministrativo T.A.R. (2007), p. 87. The new model of dynamic interpretation is spread in many legal order, in particular in the filed of human rights. In the UK for example it is required by the Human Rights Act of 1998. See on this point for example M. Arden, 'The Changing Judicial Role: Human Rights Community Law and the Intention of Parliament', 67 Cambridge Law Journal (2008), p. 487 at p. 494 et seq.

67 As has been noticed, a pluralist model has taken the place of the old fashioned hierarchical pattern in the relationship between the European and the national legal systems. In this context the judicial dialogue and the use of preliminary rulings at the constitutional level is all the more imperative. See F. Giorgi and N. Triart, 'National Judges, Community Judges: Invitation to a Journey through the Looking-Glass - On the Need for Jurisdictions to Rethink the Inter-systemic Relations beyond the Hierarchical Principle', 14 European Law Joumal (2008), p. 693 at p. 714 et seq. 
national constitutional courts as gatekeepers of the national constitutions still show quite a distrustful attitude towards the European legal system. This defensive attitude is of scanty use at the present stage of European integration; if they want to take seriously their role of custodians of the national constitutional traditions they should take a proactive style of relationship with the European court, so that all the different voices are included in the European polyphonic choir. The European Court for its part could and should do much more to encourage the dialogue with the supreme and constitutional courts, starting with a re-styling of its decisions and a re-shaping of the direct effect doctrines, so as to include the constitutional courts as qualified judges of the European system. 